\title{
THE MALE GENITAL ACCESSORY GLAND COMPLEX OF THE CATTLE TICK Boophilus microplus (CANESTRINI, 1887) (ACARI: IXODIDAE)
}

\author{
CASIMIRO GARCIA-FERNANDEZ, ${ }^{1,2}$ SONIA M. LAUER DE GARCIA ${ }^{2}$ and \\ ROSANE NUNES GARCIA ${ }^{3}$ \\ ${ }^{1}$ Instituto de Biociências, Pontifícia Universidade Católica do Rio Grande do Sul, Avenida Ipiranga, 6681, \\ CEP 90619, Porto Alegre, RS, Brazil \\ ${ }^{2}$ Instituto de Ciências Básicas da Saúde, Departamento de Ciências Morfológicas, Universidade Federal do Rio \\ Grande do Sul, Rua Sarmento Leite, 500, CEP 90046-900, Porto Alegre, RS, Brazil \\ ${ }^{3}$ Instituto de Biociências, CPG em Genética e Biologia Molecular, Universidade Federal do Rio Grande do Sul, \\ Avenida Bento Gonçalves, 9500, CEP 91501-970, Porto Alegre, RS, Brazil \\ Correspondence to: Casimiro Garcia-Fernandez, Rua Aneron Correa de Oliveira, 53, Jardim do Salso, \\ CEP 91410-070, Porto Alegre, RS, Brazil \\ Received May 19, 1997 - Accepted June 05, 1998 - Distributed August 28, 1998
}

(With 5 figures)

\begin{abstract}
A topographical and histological study of the male genital accessory gland complex of Boophilus microplus was undertaken. Ten lobes were found, the most prominent of which is the single dorsomedian lobe, subdivided into antero-dorsal and postero-dorsal lobes. The other lobes are: a pair of postero-ventral lobes, a pair of lateral lobes (subdivided into dorso-lateral and postero-lateral lobes), a pair of antero-ventral lobes, a single medio-ventral lobe and a pair of latero-ventral lobes. These lobes were observed to present individual topographical and histological characteristics, with independent openings, hence the conclusion is that they form a gland complex. The secretory nature of the dorso-median lobe duct was also analysed.
\end{abstract}

Key words: male reproductive system, genital accessory glands, ticks, Ixodidae.

\section{RESUMO}

\section{O complexo glandular genital acessório masculino do carrapato bovino Boophilus microplus (Canestrini, 1887) (Acari: Ixodidae)}

Uma análise topográfica e histológica do complexo glandular sexual acessório do sistema reprodutor masculino de Boophilus microplus foi realizada no presente trabalho. Dez lobos foram encontrados; o mais proeminente deles é o lobo ímpar dorso-mediano, subdividido em lobos ântero-dorsal e póstero-ventral. Os demais lobos são: um par de lobos póstero-ventrais, um par de lobos laterais (subdivididos em lobos dorso-laterais e póstero-laterais), um par de lobos ântero-ventrais, um lobo ímpar médio-ventral e um par de lobos látero-ventrais. Foi observado que estes lobos apresentam características topográficas e histológicas individuais, com aberturas independentes, concluindo-se, portanto, tratar-se de um complexo glandular. A natureza secretora do ducto excretor do lobo dorso-mediano também foi analisada.

Palavras-chave: aparelho reprodutor masculino, glândulas genitais acessórias, carrapatos, Ixodidae.

\section{INTRODUCTION}

In Arthropoda, the reproductive system usually possesses some kind of secretory structure, either simple cells of the epithelium that line its ducts, or accessory glands.

In general, secretion of accessory sex glands in Arthropoda is related to spermatophore forma- 
tion (Fänger \& Naumann, 1993). The secretory production of these glands can be so highly specialized that, in some instances, different spermatophore zones may come to be secreted by different cells of the accessory glands and/or other portions of the reproductive system, such as the excretory duct (Fänger \& Naumann, 1993).

In Ixodidae these glands are at first responsible for the formation of the spermatophore (Tatchell, 1962; Chinery, 1965; Oliver, 1991). Leahy \& Galun (1972) demonstrated in Argas persicus that their secretions stimulate oogenesis and vitelogenesis. Pappas \& Oliver (1972) suggested an oocyte-stimulating factor in Dermacentor andersoni. In addition, Shepherd et al. (1982) mentioned that a polypeptide $(12.5 \mathrm{Kda}$ molecular weight) from the extracts of male genital acessory glands was able to evert spermatids in vitro experiments. Also, Oliver et al. (1984) report the stimulation of the female reproductive system by male extracts.

The male accessory genital glands of ticks are located immediately posterior to the synganglion. They present a complex morphology since there are great variations according to the lobe considered. For ixodid ticks, morphological analyses of these glands were carried out by Russer (1933), Yalvac (1939), Douglas (1943), Till (1961), Chinery (1965) and Mulmule \& Thakare (1985). For argasid ticks, the glands were studied by Robinson \& Davidson (1914), Wagner-Jevseenko (1958), Roshdy (1961) and El Shoura (1987).

The ixodid Boophilus microplus is an important vector of diseases in cattle, one which is babesiosis, which affects cattle in Brazil and elsewhere. Moreover, in attaching to the bovine host, it causes direct losses in the quality of the leather (Morán, 1976).

The present work deals with a topographical and histological study of the male genital accessory gland complex of Boophilus microplus. In the proximal future the ultrastructure of each gland of the complex will be studied in the electron microscopy and also the nature of their secretions will be investigated.

\section{MATERIAL AND METHODS}

Male specimens of Boophilus microplus were collected on a dairy farm in Viamão, Rio
Grande do Sul, Brazil. Their reproductive system was dissected, drawn and photographed, with the use of a dissecting microscope.

Isolated gland complexes were fixed either in Bouin solution to be included in paraffin or in $4 \%$ paraformaldehyde to be included in historesin.

The material fixed in Bouin was dehydrated in ascending alcoholic grades and included in paraffin. Five $\mu \mathrm{m}$ sections were obtained and haematoxylin-eosin was used as stain.

The material fixed in $4 \%$ neutral buffered paraformaldehyde was dehydrated in ethanol ascending grades, pre-infiltrated in a mixture of historesin and absolute ethanol at the same proportion for 2 hours at room temperature. Infiltrations was carried out from solution A ( $\mathrm{A}^{*}$ - historesin $50 \mathrm{ml}$ to $0,5 \mathrm{~g}$ activator), in which the material remained for one night. The material was then transferred to plastic molds containing $1 \mathrm{ml}$ of solution $\mathrm{B}\left(\mathrm{B}^{*}-\right.$ infiltration solution $\mathrm{A}-15 \mathrm{ml}$, accelerator, $1 \mathrm{ml}$ ) and left at room temperature for 2 hours for polymerization. Sections of about $3 \mu \mathrm{m}$ were obtained with glass knives in an automatic microtome. Haematoxylin-eosin was also used as stain.

\section{RESULTS}

The genital accessory gland complex (Figs. 1,2 , and 3), except for the dorso-median lobe lies postero-ventrally to the synganglion and to the common vas deferens. It is composed of structurally distinct lobes. The most prominent lobe is the dorso-median which is subdivided in two regions: the antero-dorsal (ADL) and posterodorsal (PDL) lobes. From the ventral region, on the border between the anterior and the posterior region, there appears a duct that preserves the same secretory nature of the remaining gland, the excretory-secretory duct (ESD) and discharges into another duct with thinner walls, the ejaculatory duct (ED) which, in turn, runs to the genital opening. The remaining lobes comprising the accessory gland complex are listed below as they appear in a postero-anterior direction:

- a pair of postero-ventral lobes (PVL), which open in the bordering region between the excretory-secretory duct (ESD) of the dorsal median lobe (DML) and the thin-walled duct, the ejaculatory duct (ED), that discharges into the genital opening; 
- a pair of lateral lobes, subdivided in a pair of dorso-lateral lobes (DLL) and a pair of postero-lateral lobes (PLL);

- a pair of latero-ventral lobes (LVL);

- a single medio-ventral lobe (MVL);

- a pair of antero-ventral lobes (AVL).

The pairs of lateral, latero-ventral and anteroventral lobes and the single medio-ventral lobe open in the thin-walled duct, ejaculatory duct, which discharges into the genital opening and also receives the opening of the common vas deferens.

\section{Dorso-median lobe}

Antero-dorsal lobe

It begins in a cephalic position, almost overlaying the synganglion. In its anterior region it appears bifurcated, forming two lateral sacs that project anteriorly and laterally. These sacs appear to be joined at the median region forming a single chamber, which ultimately constricts to give rise to the postero-dorsal lobe, a markedly larger structure. (Figs 1, 2, 3 - ADL, PDL).

This lobe consists of narrow, columnar secreting cells which are juxtaposed, have illdefined limits and nuclei at varying levels. The gland lumen is large and well-defined (Figs. 4 A-F). The secreting cells nuclei are elongated or rounded, presenting a very compact chromatin. Basal and rounded nuclei are also observed. The secretion present in the cells is made up of little acidophilic granules.

Regionalizations are observed in this lobe, which presents cells completely filled with granules or cells with clear cytoplasm. As transversal sections toward the median region of the lobe are examined, cells of the ventral wall become taller, displaying clear cytoplasm and gland secretion accumulated in the apical region (Fig. 4E and $\mathrm{F}-\mathrm{ADL}$ ).

Externally, the whole dorso-median lobe is lined with squamous cells, with compact nucleus and eosinophilic cytoplasm.

\section{Postero-dorsal lobe}

Initially single, it soon displays an external longitudinal constriction which subdivides it caudally into two identical sacs. Internally, the constriction is accompanied by a septum which gives rise to tw o chambers (Fig. 4G and J-PDL).

Ventrally, at a point in the limit between the antero-dorsal and postero-dorsal lobes, there appears the excretory-secretory duct that runs anteriorly (Figs. 4G and $\mathrm{H}, 5 \mathrm{~A}$ and $\mathrm{B}-\mathrm{ESD}$ ), receiving in its most proximal part the discharge from postero-ventral lobes (Fig. 5C - ESD, PVL), and
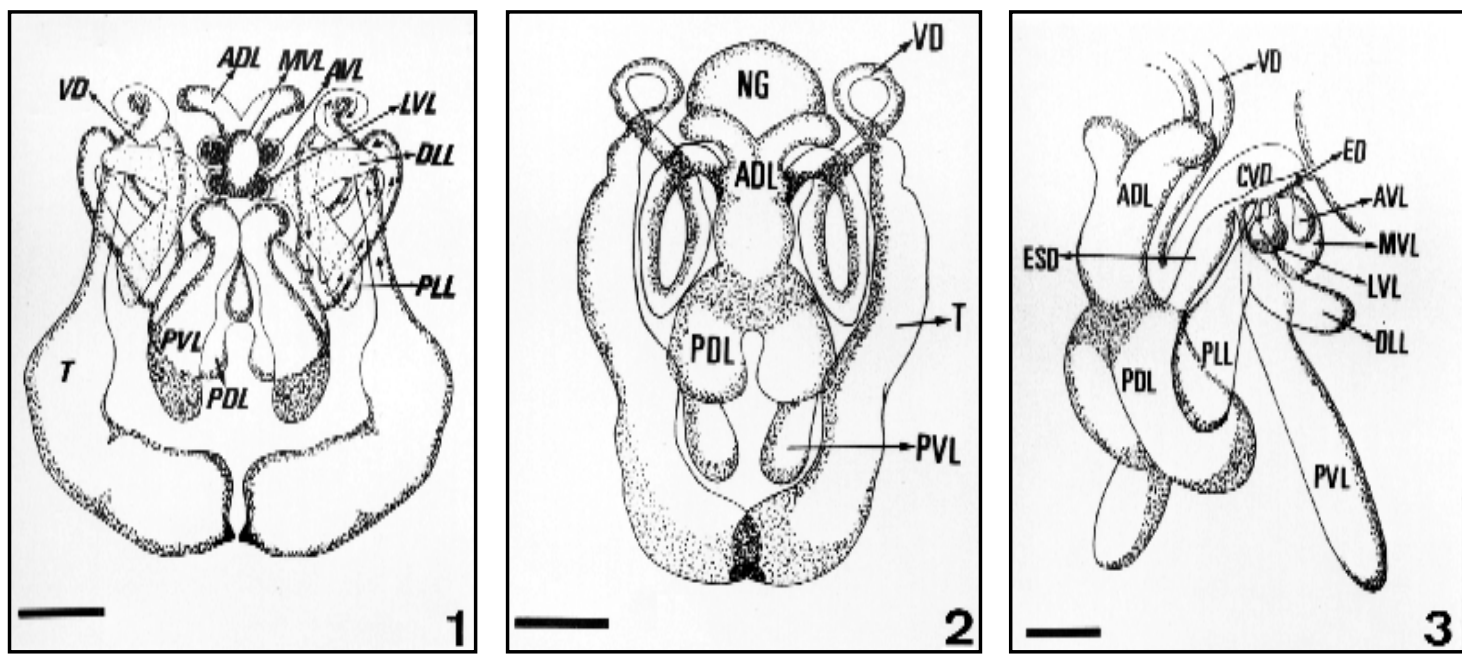

Figs. 1-3 - Male accessory sex gland complex of Boophilus microplus. 1 - Ventral view; 2 - Dorsal view; 3 - Lateral view. In Fig. 3 the dorso-median lobe was drawn dorsally to show the transition from the excretory-secretory duct to the thin-walled duct - ejaculatory duct. Scale bars $=0,5 \mathrm{~mm}$. ADL - antero-dorsal lobe; AVL - antero-ventral lobes; DLL dorso-lateral lobes; ED - ejaculatory duct; ESD - excretory-secretory duct; LL - lateral lobes; LVL - latero-ventral lobes; MVL - single medio-ventral lobe; PDL - postero-dorsal; PLL - postero-lateral lobes; PVL - postero-ventral lobes; T - testis; VD - vas deferens. 
further extending as a duct with a smaller diameter, namely, the ejaculatory duct (Figs. 5A arrow and 5D - ED), which, before opening to the outside, receives the discharge from the remaining lobes, as well as from the common vas deferens (Fig. 5D - arrow).

Though the postero-dorsal lobe presents different regionalizations, these are histologically similar. The epithelium that composes this lobe consist of narrow, tall cells resting on the basal lamina, as in the antero-dorsal region of this lobe (Figs. 4G and J-PDL). Basal squamous cells are also observed lining the gland lobe externally. The secreting cells show a variety of secretions, with some cells containing basophilic granules and others showing homogeneous and acidophilic secretion. In the broad and well-defined lumen, the secretion is granular or homogenous and colloidal in aspect.

At least three distinct groups of secretory cells are observed in the most dilated part of the gland wall, opposite and lateral to the appearance of the excretory duct: in the mid portion of the dorsal wall, opposite the excretory-secretory duct, cells are clearer and filled with a finely granular material and slightly larger granules, and the presence of a clear homogeneous secretion is also observed (Fig. 5B - thin arrow); on the lateral walls of this lobe, cells present a fine granular, highly eosinophilic material, as well as dense drops of homogeneous acidophilic secretion (Fig. 5B - broad arrow); though at the end of the lateral walls, reaching the walls that form the excretory-secretory duct, the histological nature is similar to the rest of the gland, the secretion is predominantly granular and not so eosinophilic (Fig. 5B - asterisk).

The wall of the septum that divides internally the postero-dorsal lobe into two chambers is histologically similar to the rest of the lobe and also displays a secretory character (Fig. $4 \mathrm{I}-\mathrm{S}$ ).

\section{Excretory-secretory duct}

Initially it has a secretory character, displaying similar histology to the dorso-median lobe from which it arises (Figs. 3, 4E and $\mathrm{H}$ and 5A and C - ESD).

As it approaches the thin-walled duct, the ejaculatory duct, its cells become lower and lower, losing their secretory character (Figs. 4D ESD and $5 \mathrm{~A}-$ arrow). In its bordering region with the ejaculatory duct, it receives the discharge from the pair of postero-ventral lobes (Fig. 5C).

\section{Postero-ventral lobes}

They correspond to a pair of elongated glands that run caudally, trav ersing the posterodorsal lobe (Figs. 1, 2 and 3 - PVL). They discharge into the excretory-secretory duct of the postero-dorsal lobe at its connection with the thin-walled duct (Fig. 5C). These lobes are constituted by two histologically distinct zones. Most of them is made up of secretory cuboid or pyramidal cells, with nuclei located at the lower third with compact chromatin.

They present regular and clearly eosinophilic granular material in the portion above the nucleus through the cell apex. The basal portion of the secreting cell shows a homogeneous and basophilic cytoplasm (Fig. 5E - PVL).

In the gland portion near the opening into the excretory-secretory duct, the secreting cells present a distinct histological aspect. At this level, some of the nuclei of the secretory cells are relatively large while others are very small. Both are rounded and have a compact chromatin. The cells of this region display a compact and highly acidophilic cytoplasm with indistinguishable cell borders. Sometimes cells in this region are highly vacuolated (Figs. 5C and F - PVL).

\section{Lateral lobes}

These consist of a pair of lobes that open before the postero-ventral lobes, reaching the thin-walled duct. Each component of the pair presents its gland body subdivided into two lobes: the dorso-lateral and postero-lateral lobes. Its configuration is Y-shaped.

Steresoscopic microscopy of this lobe reveals a lighter tone than the remaining lobes. Both dorso-lateral lobes run in caudal direction, dorsally, while the two ventro-lateral lobes run in caudal direction, ventrally (Figs. 1 and 3 DLL, PLL).

Histologically identical to each other, these glands present cells with undefined borders, and may appear fined with eosinophilic granules or highly vacuolated cytoplasm. Their nuclei are extremely compact and pycnotic. Within the wide gland lumen, the secretion observed may be colloidal or granular, but it is invariably acidophilic. (Figs. 4D and E and 5G - LL). 

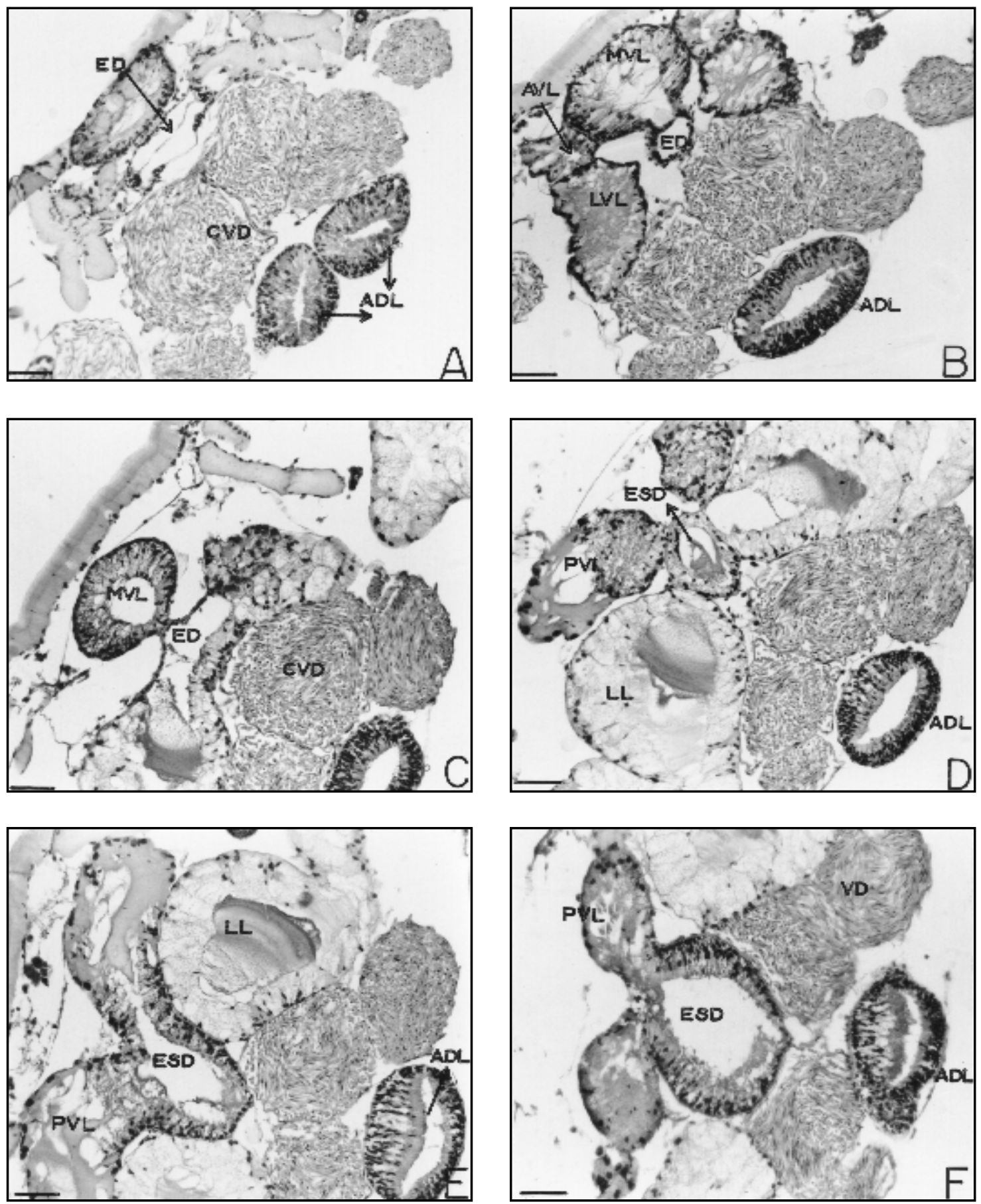

Fig. 4 A-J - Sequence of transversal histological sections through the male accessory gland complex of Boophilus microplus, showing the discharge of the different lobes into the excretory-secretory duct (D-H) of postero-ventral lobe or into the ejaculatory duct (A-C) (thin walls). Haematoxylin-eosin stain. Scale bars $=10 \mu \mathrm{m}$. ADL - antero-dorsal lobe; AVL antero-ventral lobes; ED - ejaculatory duct; LL - lateral lobes; LVL - latero-ventral lobes; MVL - single medio-ventral lobe; PVL - postero-ventral lobes; VD - vas deferens. 

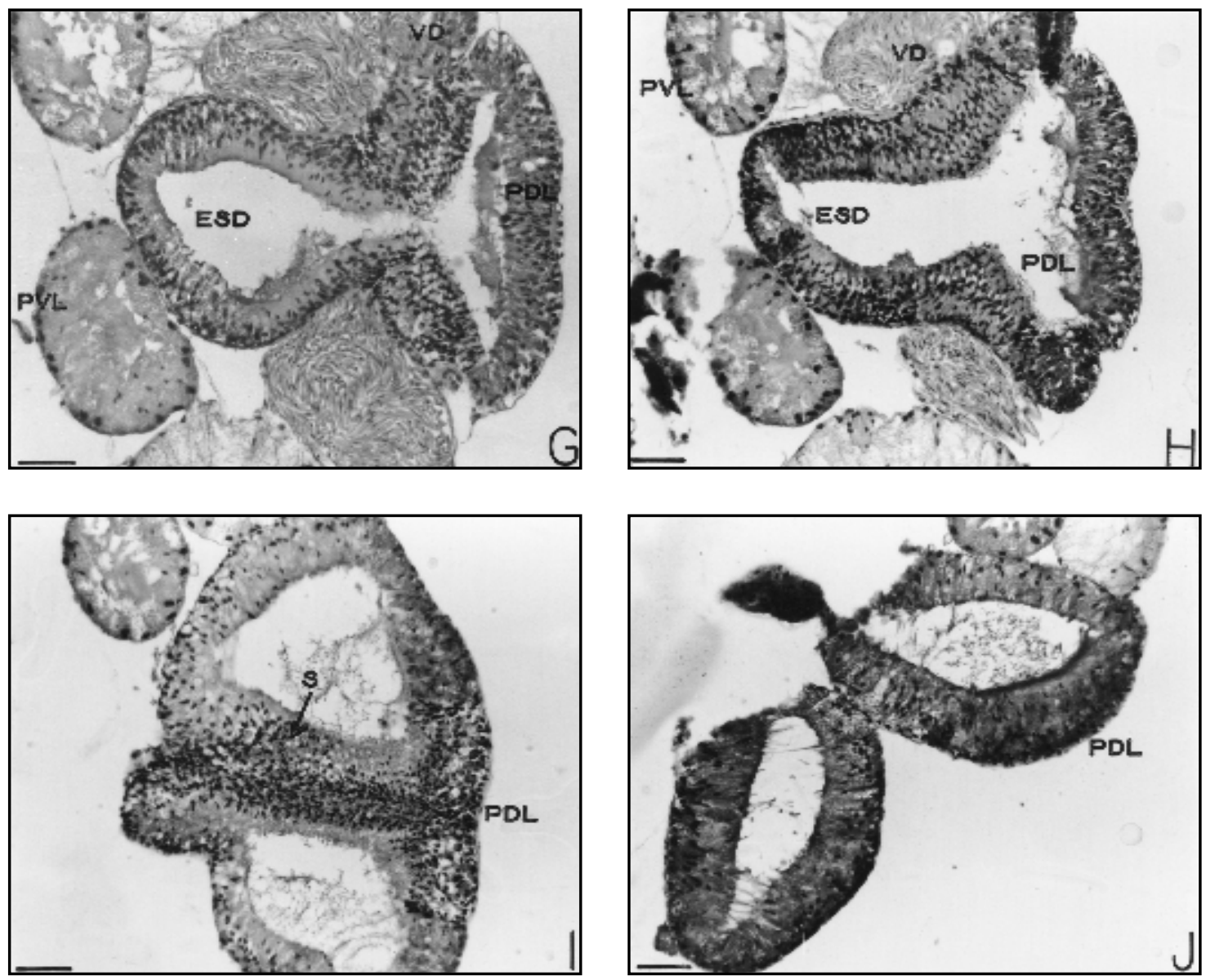

Fig 4 A-J (cont.) - Sequence of transversal histological sections through the male accessory gland complex of Boophilus microplus, showing the discharge of the different lobes into the excretory-secretory duct (D-H) of postero-ventral lobe or into the ejaculatory duct (A-C) (thin walls). Haematoxylin-eosin stain. Scale bars $=10 \mu \mathrm{m}$. ESD - excretory-secretory duct; PDL - postero-dorsal; PVL - postero-ventral lobes; S - Septum; VD - vas deferens.

\section{Antero-ventral, medio-ventral and latero- ventral lobes}

Ventrally, at a proximal position and right below the antero-dorsal lobe of the dorso-median lobe, there are five glands (two paired and one single) surrounding ventrally and laterally the ejaculatory duct: a pair of antero-ventral lobes, a single medio-ventral and a pair of latero-ventral lobes. Owing to their localization, more cephalic and circumscribing the thin-walled duct, we will call this group of lobes as the "necklace" (Figs. 1 and $3-$ AVL, MVL, LVL).

\section{Antero-ventral lobes}

Histologically these are the most peculiar parts of the "necklace" group due to the vacu- olated aspect and intense basophilic cytoplasm of their cells.

The nuclei are distributed irregularly and most of them are highly compact. The cell borders are difficult to define. Externally to the secreting cells are squamous cells whose nuclei contain highly compact chromatin. The lumen is poorly defined (Fig. 5H - AVL).

\section{Medio-ventral lobe}

This is a single lobe and the most central of the "necklace" group. It is a globose structure, the largest of this group.

Its histology bears some resemblance with that observed in the dorso-median lobe, since it presents, too, an epithelium made up of tall cells 
filled with secretory granules, nuclei at different levels, compact chromatin and secretion of two types: eosinophilic granules or a non-granular secretion, forming large drops as they fall into the lumen. Externally it appears lined by a squamous epithelium. Its lumen is evident, filled with both granular and colloidal secretion (Fig. 5I - MVL).

\section{Latero-ventral lobes}

These correspond to a pair of globose glands. Histologically their secreting cells possess rounded borders, nuclei with compact chromatin and eosinophilic granular secretion of variable sizes, though zones of dense and homogenous secretion are also observed.

Large vacuoles filled with scarce granules are noted. the lumen is not clear-cut (Fig. 5J LVL).

\section{DISCUSSION}

The morphology of male genital accessory glands of Boophilus microplus is similar to that reported for other ixodid ticks (Russer, 1933; Douglas, 1943; Till, 1961; Chinery, 1965; Mulmune \& Thakare, 1983). Some dissimilarities were observed as listed below:

1. The ventral prolongation of the mediandorsal lobe is regarded by Chinery (1965) as the collecting duct because along its course it receives the discharge of the other components of the accessory gland in Haemaphysalis spinigera. this structure in Rhipicephalus appendiculatus is considered by Till (1961) as the median part of the dorso-median lobe. In Boophilus microplus it has a clear-cut secretory character and does not receive the discharge from the other lobes, except for the postero-ventral lobes which open in their bordering region with the thin-walled duct. Since in Boophilus microplus the remaining lobes discharge into the thin-walled duct, and as the duct of the dorso-median lobe has secretory characteristics, we consider it as an excretory-secretory duct of the dorso-median lobe. On the other hand, the thin-walled duct that receives the other lobes and the discharge of the common vas deferens was the ejaculatory duct.

2. The lobes present in the genital accessory complex of Boophilus microplus correspond to those described by Chinery (1965) for Haemaphysalis spinigera. Mulmule \& Thakare (1985) showed a correspondence between the gland lobes in Rhipicephalus sanguineus and those described by Chinery (1965) in Haemaphysalis spinigera. However, Mulmule and Thakare (1985) reported a lobe, referred to as the dorso-lateral lobe, that was observed neither in Haemaphysalis spinigera nor in Boophilus microplus. The structure referred to by Mulmule and Thakare does not correspond to the dorso-lateral lobe reported for Haemaphysalis spinigera and Boophilus microplus. It corresponds to one of the lateral lobes in these two species. Even more, Mulmule and Thakare designated as postero-lateral the corresponding lateral lobes in Haemaphysalis spinigera and Boophilus microplus. What is called by Chinery (1965) in Haemaphysalis spinigera and in the present work in Boophilus microplus as postero-lateral lobe corresponds to a region of the lateral lobes, once that in Haemaphysalis spinigera and in Boophilus microplus, the lateral lobes are subdivided in two regions, the dorso-lateral an postero-lateral lobes.

The histological analysis of the dorso-median lobe in Boophilus microplus shows a variety of secretions, whether among regions of the lobe or among cells belonging to the same region. This characteristic was observed in Haemaphysalis spinigera by Chinery (1965) when the presence of secretory granules of varying sizes was reported. Studying Rhipicephalus sanguineus, Mulmule \& Thakare (1985) regionalized the secretory activity of the median lobe in the postero-dorsal portion in five areas which they called categories A, B. C, D and E. In Boophilus microplus, the presence of regionalization in the postero-dorsal portion of the median-dorsal lobe is evident, and at least three regions were established in the present study.

Comparison between gland lobes of Boophilus microplus with specimens from the argasid group is difficult because there appears to be no complete correspondence among them. However, the dorso-median lobe is constant in all cases reported in the literature and is always the most prominent one.

Robinson \& Davidson (1914) have histologically classified the male genital accessory gland of Argas persicus in two great groups: spongy and granular. They describe the "spongy tissue" as constituted by a stroma of connective tissue with lacunae filled with a light, pale secretion. 

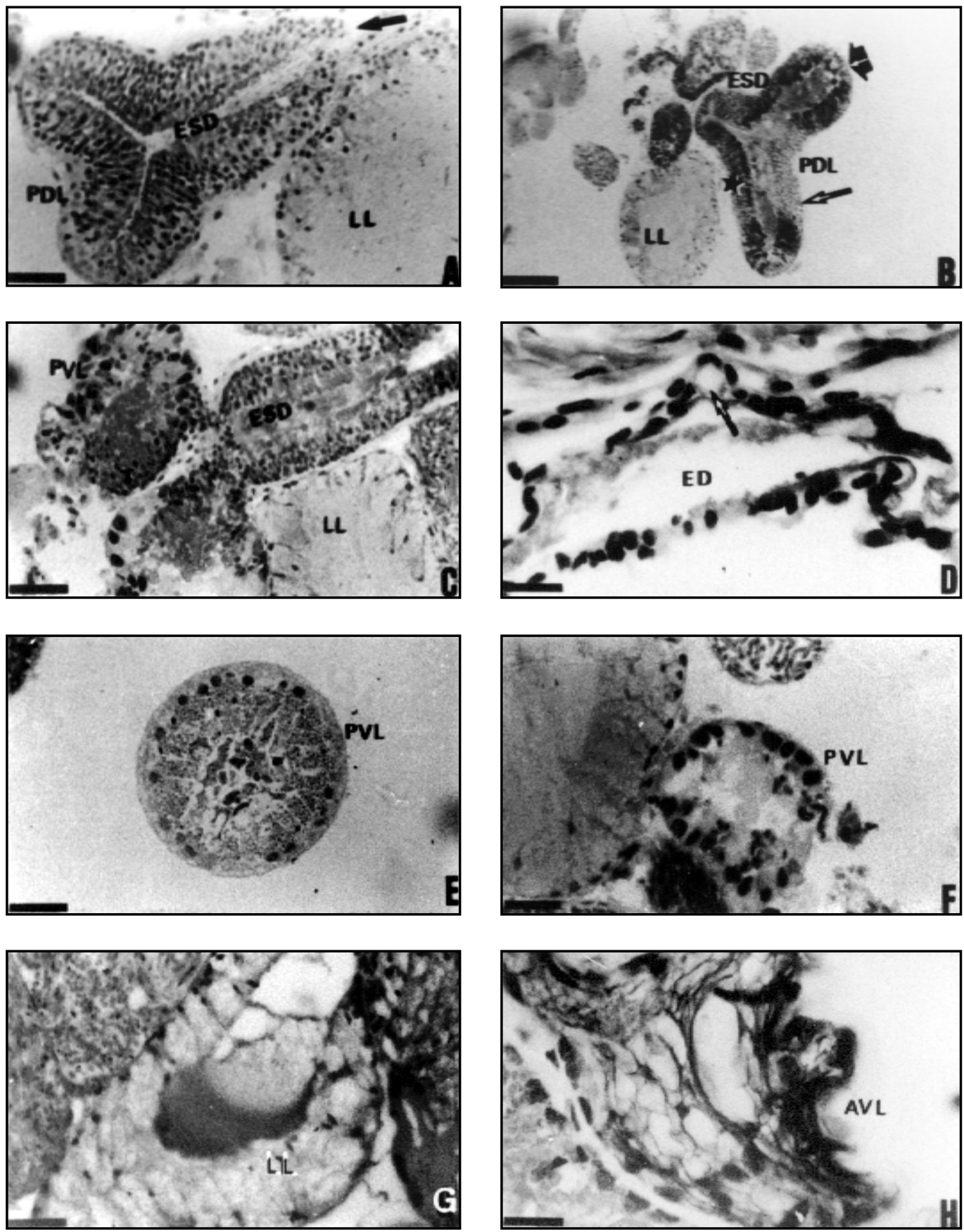

Fig. 5A-H - Histological sections of the different lobes of the accessory sex gland of Boophilus microplus. Haematoxylin-eosin stain. A - Dorso-median lobe (DML) and excretory-secretory duct (ESD) discharging into the thin-walled duct (arrow), lateral lobes (LL); B - Dorso-median lobe in its posterior region postero-dorsal lobe (PDL) showing the beginning of the compartmentalization and its fusion with the excretory-secretory duct (ESD). Note cells with light cytoplasm (arrows), strongly stained cells (arrow heads) and cells with intermediate staining (asterisks); lateral lobes (LL); C - excretory-secretory duct (ESD) and discharge from the postero-ventral lobes (PVL), lateral lobes (LL); D — Thin-walled duct, in this region corresponding to the ejaculatory duct (ED) and discharge from the common vas deferens (arrow); E - Distal region of the postero-ventral lobes (PVL); F — Proximal portion of the postero-ventral lobes (PVL) near their discharge into the excretory-secretory duct; G - lateral lobes (LL); H - antero-ventral lobes (AVL). Bars correspond to $50 \mu \mathrm{m}$ in $\mathrm{A}, \mathrm{C}, \mathrm{E}$ and $\mathrm{F}$; to $100 \mu \mathrm{m}$ in $\mathrm{B}$ and to $25 \mu \mathrm{m}$ in $\mathrm{D}, \mathrm{G}$ and $\mathrm{H}$. 

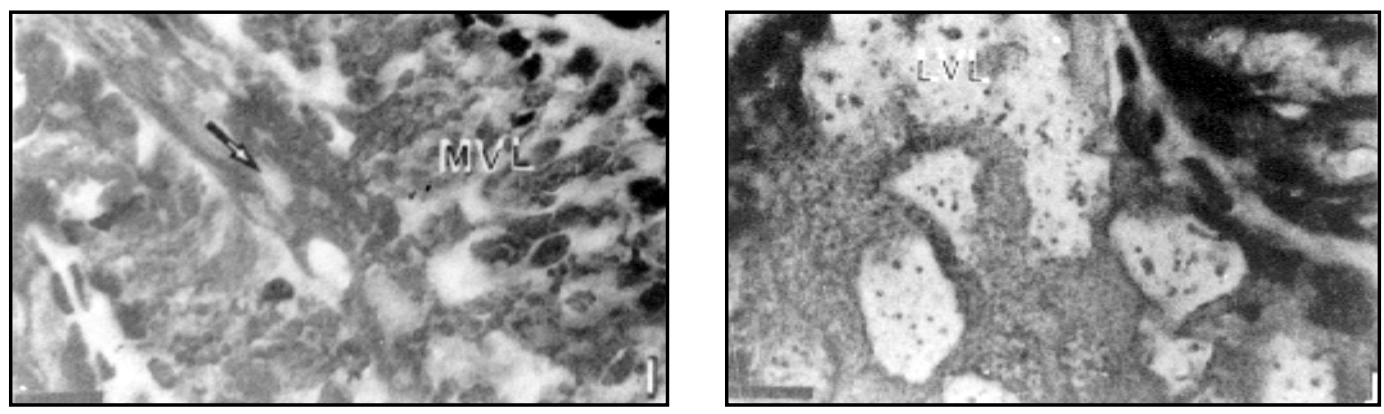

Fig. 5I-J - Histological sections of the different lobes of the accessory sex gland of Boophilus microplus. Haematoxylin-eosin stain. I - single medio-ventral lobe (MVL), gland lumen (arrow); J - latero-ventral lobe (LVL). Bars correspond to $25 \mu \mathrm{m}$ in $\mathrm{I}$ and $\mathrm{J}$.

Granular lobes are described as constituted by cylindrical cells filled with irregular granules. Later, Russer (1933) and Douglas (1943) described spongy and granular tissue in genital accessory glands of Hyalomma aegyptium and Dermacentor andersoni, respectively. However, Till (1961) and Chinery (1965), in studying Rhipicephalus appendiculatus and Haemaphysalis spinig era, respectively, considered that all lobes are granular, since they do not display this granular aspect until short after the tick has begun to feed.

On the other hand, Chinery (1965) concluded that the reticular aspect of the dorso-lateral and postero-lateral lobes, in the absence of granules, would bear some resemblance with the "spongy" tissue in Argas persicus. Mulmule \& Thakare (1985), studying the genital accessory glands in Rhipicephalus sanguineus, largely agree with Till (1961) and Chinery (1965).

In our observation in Boophilus microplus it became clear that some lobes, namely, the pair of lateral lobes, the antero-ventral pair and the latero-ventral pair, do show a "spongy" aspect due to the presence of a great number of cell vacuoles.

All the remaining lobes are predominantly granular. We have considered these as histological characteristics of the gland lobes, since we have worked with adult specimens. It was also mentioned and justified by El Shoura (1987) that the appearance of granular or spongy lobes in the accessory genital glands of Ornithodorus (pavloskyella) erraticus does not represent any specific phase of secretory activity because the secretory lobes had always the same appearance.
Acknowledgements - The authors are indebted to biologist Eliane de Oliveira Borges, technician of the Laboratory of Histology and Embriology of the Morphological Sciences Department of the Universidade Federal do Rio Grande do Sul, for her collaboration in the preparation of histological sections in paraffin. This work was supported by Propesp/ UFRGS and CNPq/UFRGS.

\section{REFERENCES}

CHINERY, W. A., 1965, Studies on the various glands of the tick Haemaphysalis spinigera Neumann, 1897. Acta Trop., 22(3): 235-266.

DOUGLAS, J. R., 1943, The internal anatomy of Dermacentor andersoni Stiles. Univ. Calif. Publ. Entomol., 7: $207-$ 272.

EL SHOURA, S. M., 1987, Fine structure of the vase deferentia, seminal vesicle, ejaculatory duct, and accessory glands of male Ornithodoros (Pavlovskyella) erraticus (Acari: Ixodoidea: Argasidae). J. Med. Entomol., 24(2): 235-242.

FÄNGER, H. \& NAUMANN, M.,1993, Correlation between the mesodermal male genital ducts and the spermatophore structure in a ditrysian moth, Zygaena trifolii (Esper, 1783) (Insecta, Lepidoptera, Zyg aenidae). Acta Zool., 74(3): 239-246.

LEAHY, M. G. \& GALUN, R., 1972, Effect of mating on oogenesis and oviposition in the tick, Argas persicus (Oken). Parasitology, 65: 167-178.

MORÁN, C. G. R., 1976, Investigaciones realizadas en el campo de la parasitología veterinaria. Ministerio del Desarollo Agropecuario, Universidad de Panama, 56.

MULMULE, S. \& THAKARE, V. K., 1985, Cytology and cytochemistry of male acessory gland in the dog tick, Rhipicephalus sanguineus (L.) (Acarina: Ixodidae). Z. Mikrosk. Anat. Forsch., 99(1): 25-36.

OLIVER JR., J. H., 1991, Tick reproduction: sperm development and cytogenetics. In: F. Obenchain \& R. Galun (eds.), Physiology of Ticks, 245-275. Perg amon Press, New York. 
OLIVER JR., J. H.; POUND, J. M. \& ROSS, H. A., 1984, Induction of egg maturation and oviposition in the tick Ornithodoros parkeri (Acari: Argasidae) J. Parasit., 70(3): 337-342.

PAPPAS, P. J. \& OLIVER JR., J. H., 1972, Reproduction in ticks (Acari: Ixodoidea). 2. Analysis of the stimulus for rapid and complete feeding of female Dermacentor variabilis (Say.). J. Med. Entomol., 9: 47-50.

ROBINSON, L. E. \& DAVIDSON, J., 1914, The anatomy of Argas persicus Oken. Parasitology, 6: 342-424.

ROSHDY, M. A., 1961, Comparative internal morphology of subgenera of Argas ticks (Ixodoidea, Argasidae). 1. Subgenus Carios: Argas vespertilionis (Latreille, 1802). J. Parasit., 47: 987-994.

RUSSER, M., 1933, Beiträge zur kenntnis des Chitins und der Muskulatur der Zecken (Ixodidae). Z. Morph. Oek. Tiere, 27: 199.
SHEPHERD, J. G.; OLIVER, J. H \& HALL, J. D., 1982, A polypeptide from male accessory glands which triggers maturation of tick spermatozoa. Int. J. Invertebrate Reprod. and Develop., 5: 129-137.

TATCHELL, R. I., 1962, Studies on the male acessory reproductive gland and the spermatophore of the tick Argas persicus (Oken.). Parasitology, 52: 133-142.

TILL, W. M., 1961, A contribution to the anatomy and histology of the brown tick, Rhipicephalus appendiculatus Neumann. Mem. Ent. Soc. Southern Africa, 6: 1-24.

WAGNER-JEVSEENKO, O., 1958, Fortpflanzung bei Ornithodorus moubata und genitale Ubertragung von Borrelia duttoni. Acta Trop., 15: 118-168.

YALVAC, S., 1939, Histologische Untersuchungen über die Entwicklung des Zeckenadults in der Nymphe. Z. Morph und Oek. Tiere, 35. 